\title{
Spooler Device
}

National Cancer Institute

\section{Source}

National Cancer Institute. Spooler Device. NCI Thesaurus. Code C50186.

An electronic device designed to set files into a queue for processing, especially one for controlling the output to a printer. 